\title{
Genre-Based Approach to Writing Instruction for Students at an English Language and Literature Department
}

\author{
Gamze Almacioğlu ${ }^{a}$ * (iD), Zuhal Okan ${ }^{b}$ \\ ${ }^{a}$ Gaziantep University, Gaziantep 27060, Turkey \\ ${ }^{b}$ Çukurova University, Adana 01330, Turkey
}

Received 21 December 2017 | Received in revised form 21 February 2018 | Accepted 26 March 2018

\begin{abstract}
The aim of the genre-based pedagogy is to focus on students' academic needs and enable them to read and write successfully (Martin, 1993, 2009). Therefore, it is imperative for teachers to understand the range of written genres and other writing skills that students need to use in their academic studies. This study has aimed to design an alternative and effective way of teaching writing to English Language and Literature students within the genre-based pedagogy considering their academic needs. The present study attempts to investigate the process of building metacognitive genre-awareness and show how it influences English Language and Literature students' ability to interpret and compose academic texts. The present study is designed as a case study, and mixed methods of data collection and analysis have been adopted. Several sources of data coming from both the teacher herself and the students such as classroom observation and teacher's journal, students' written texts (portfolios), students' diaries and interview with students have been used to have a deeper understanding of the process of genre-based writing instruction. The results of the study indicate that most of the students acquired, at least, metacognitive awareness of the declarative type, they seem to move their writing ability up and there is a general improvement in their writing performance.
\end{abstract}

(C) 2018 EJAL \& the Authors. Published by Eurasian Journal of Applied Linguistics (EJAL). This is an open-access article distributed under the terms and conditions of the Creative Commons Attribution license (CC BY-NC-ND) (http://creativecommons.org/licenses/by-nc-nd/4.0/).

Keywords: Genre-based academic writing instruction; metacognitive genre awareness; analysis of academic and literary texts

\section{Introduction}

\subsection{Genre acquisition/learning vs genre awareness}

Instead of genre acquisition/learning, if students develop genre awareness through pedagogies providing "guidance to structure specific problems and learnings into more abstract principles that can be applied to new situations" (Beaufort, 2007, p. 151), they are able to improve "high road" or "far" transfer of learning. In other words, they can "successfully apply old knowledge to a new problem" (Willingham, 2009, p. 74). Thus, there is a distinction between pedagogies that support genre

\footnotetext{
* Gamze Almacioğlu

E-mail address: gamzekulekci@gmail.com

http://dx.doi.org/..
} 
learning/acquisition with the repeated analysis and practice of fixed text formats and those that support genre awareness.

With this kind of a genre-based writing instruction whereby teachers and students manage to go beyond a prescriptive initiation into disciplinary conventions (Tribble, 1996) they will be enabled to take a critical view of the context of these conventions. Moreover, critical awareness of writing practices, suitable discipline-specific texts for students and how writers organize texts can be listed to employ and manipulate this type of writing instruction and "to meet the anticipated goal and purpose" (Kay \& Dudley-Evans, 1998, p. 310).

Therefore, what we like to pursue in this research is the examination of the process of building metacognitive genre-awareness within genre-based academic writing instruction and see how it influences English Language and Literature students' ability to interpret and compose academic texts.

\subsection{Genre awareness with literature students}

Genre-based pedagogies offer a valuable resource for assisting students' ability to both comprehend and produce texts. The distinctive features and benefits of this model are "(i) its focus on grammar as a meaning-making resource and (ii) its focus on text as semantic choice in social context" (Martin, 2009, p. 11). Genre-based pedagogies put language, content and contexts together with explicit explanations in a systematic way "instead of focusing on the process of composition, the content of texts, or the abstract prescriptions of disembodied grammars" (Hyland, 2007, p. 150).

However, to benefit from its positive sides, genre learning should also be applied carefully according to the students' needs in writing classrooms. A general understanding about genre learning is “.... essays or paragraphs with strict formats in the rhetorical modes are central and structure is often taught as fixed and almost universally transferable" (Johns, 2011, p. 57). In these kinds of genre-based pedagogies, students are supposed to learn text types and use these texts in the related contexts. According to the students' needs, this kind of genre learning can be sufficient and effective for beginner students or in the preparatory writing classrooms. On the other hand, a more sophisticated and detailed approach should be put into use with advanced students or for students who use English language for academic purposes. In that sense, they should be encouraged to develop genre awareness instead of memorization of text types. In this research, the genre-based pedagogy which supports genre awareness, described by Beaufort (2007, p. 151) as providing "guidance to structure specific problems and learnings into more abstract principles that can be applied to new situations" will be followed within a genre-based academic writing instruction. When the literature students' academic needs are taken into consideration, their language knowledge, discourse competence and reflective thinking abilities should be enhanced with real samples of language through a conscious analysis of genres. 


\subsection{Genre and metacognitive awareness}

Genre can be defined as "abstract, socially recognized ways of using language" (Hyland, 2007, p. 149) and it has become "one of the most important and influential concepts in language education" (Hyland, 2004, p. 5). We need to consider that there are several genre theories and pedagogies; however, in the context of L2 academic writing, the ESP School has been very influential, particularly in teaching specialist varieties of English to graduate students (e.g. Swales, 1990, 2004; Swales \& Feak, 2000, 2004).

In order to understand whether this kind of an approach toward teaching writing is really beneficial and successful to reach the aimed objectives of the course not only in theory but also in practice, questions such as what students think and feel about genre-based writing tasks, what they learn from them, and how they incorporate the insights gained through genre-based instruction into their own writing need to be answered. There are some prominent studies that were conducted with similar questions at the beginning (Cheng, 2007; Yayli, 2011). In line with the findings of these studies, how to build metacognitive awareness within ESP genre-based academic writing instruction is also addressed in this study.

Metacognition, the ability to reflect upon one's knowledge and control one's thinking (Flavell, 1979), is thought to support learners in perceiving relevant aspects of a task and therefore influences their ability to make strategic choices. Metacognitive strategies regulate their learning across disciplinary areas and learning situations (Azevedo \& Whiterspoon, 2009; Veenman, Wilhelm, \& Beishuizen, 2004; Zimmerman \& Schunk, 2001). Schraw and Dennison (1994) have defined metacognitive awareness as the ability to know when and how/ why cognitive strategies should be applied. Also, in Shraw's study (1998), it is argued that students who have metacognitive abilities can adapt their learning strategies to different contexts. The distinction between two components of metacognition is accepted by most of the researchers: knowledge of cognition and regulation of cognition (Dunlosky \& Metcalfe, 2009; Serra \& Metcalfe, 2009; although see Flavell (1987) for an alternative view).

Knowledge of cognition refers to learners' awareness of their knowledge, of the task, and their thinking/ learning strategies; and it includes three different kinds of metacognitive awareness: declarative, procedural, and conditional knowledge (Brown, 1987; Jacobs \& Paris, 1987; Schraw \& Moshman, 1995). Shraw (1998, p. 114) states that "declarative knowledge refers to knowing 'about' things. Procedural knowledge refers to knowing 'how' to do things. Conditional knowledge refers to knowing the 'why' and 'when' aspects of cognition." On the other hand, metacognitive regulation refers to how learners use metacognitive awareness to monitor and control their own thinking and learning or in another way, it refers to a set of activities that help students control their learning (Shraw, 1998). 
Gombert's (1993) definition of meta-pragmatics can be considered for a deeper understanding of the relationship between metacognition and writing because he underlines the special nature of metacognition with regard to verbal communication. The pragmatic aspects of language use are covered by metacognitive knowledge of language and the pragmatic aspects of language use are arranged according to the different communicative contexts, in the case of writing, to different genres.

For this reason, students' reading and writing strategies can be developed by fostering their metacognitive knowledge of the rhetorical situation and of genrerelevant aspect to diverse contexts of academic communication (Negretti \& Kuteeva, 2011). Metacognition plays a role in every stage of the writing process. Learners need it from the analysis of the task to the linguistic choices while they are putting thoughts into words and to the revising and editing processes, which take place during and after the writing activity (Bereiter \& Scardamalia, 1987; Breetvelt, Bergh, \& Rijlaarsdam, 1994; Hacker, Keener, \& Kircher, 2009; Kellogg, 1994; Myhill \& Jones, 2007).

Negretti (2009) mentions the importance of metacognitive awareness of rhetorical and genre-relevant aspects. In her study, she states that these aspects such as appropriateness of topic, purpose of the text, audience expectations and effectiveness of argumentation imbue every moment of the writing experience. In their study, Negretti and Kuteeva (2011) also state that "genre awareness ties closely with metacognitive knowledge" (p. 96). They tried to trace "the development of students' genre awareness (Devitt, Reiff, \& Bawarshi, 2004) of research-based writing and interpret this process using the framework of metacognition theory" (Negretti \& Kuteeva, 2011, p. 96). They suggest that "the body of research on metacognition, its underlying processes, and its relevance for students' ability to learn and gauge performance" can provide knowledge about "how awareness of genre, discourse, and rhetoric comes into play when students read and write texts that are situated in different contexts" (p. 96).

In short, among the four language skills, writing is perhaps one of the most difficult and important one for students with non-native English background. Some methods like The Communicative Language Teaching and the Process Writing Approach have usually been preferred in the teaching of writing skill for years in Turkey. As a result, although students have been working on how to develop their writing skills, they turn out to be poor writers. The problem for students who are supposed to deal with academic writing has been even more complicated. The shortcomings of writing instruction at university level has negatively affected students' ability to use the English language, express their thoughts, feelings, opinions in English and their attitudes, motivation and achievement in general. Instead of teacher-directed, product oriented practice a more process oriented writing instruction with paying attention to context, reader-writer relationship or purpose is needed to be introduced and implemented by the teachers. In that sense, genre-based approaches, which analyse language varieties in particular disciplines are very suitable and effective for the university education, where students specialise in their discipline. Therefore, what we 
like to pursue in this research is to provide a detailed analysis about the application of genre-based approaches to writing practice by examining the process of building metacognitive genre-awareness within genre-based academic writing instruction and see how it influences English Language and Literature students' ability to interpret and compose academic texts. In the light of these points three research questions were formulated to guide the study:

1. To what extent does genre-based academic writing instruction contribute to raising metacognitive genre awareness in English Language and Literature students?

2. If so, how does this metacognitive genre awareness affect English Language and Literature students' analysis of academic and literary texts?

3. How does, if any, this metacognitive genre awareness affect English Language and Literature students' writing performance?

\section{Method}

\subsection{Participants}

The target population of the study was the first year English Language and Literature undergraduate students from a state university in Turkey during 2014 2015 academic year. The total number of the students in the department was around 300 students and 110 of them were the first year students who were the target population of this study (for the first semester, 115 students registered but 104 of them attended; for the second semester, 108 students registered but 93 of them attended).

Writing was one of the compulsory courses in the first year and all of the students were supposed to take the course because it was aimed that students could reach the adequate level in reading and writing English texts with this course. Participants were used to genre-based writing instruction from their prep-class; however, that course covered a general syllabus prepared for the students of all departments in the university. Thus, our design is not totally new for them but it is new in content and its objectives. The reasons for the choice of this group of participants were

(1) the convenience sampling method was used and students took part in the writing class taught by one of the researchers;

(2) that instructor was giving the course, and experiencing the insufficient parts of the course during the years. The need of accommodating genre-based writing instruction with a more specific content for students who were studying English Language and Literature urged the researchers to conduct the present study.

With a consent form, students' consent was affirmed to be a part of the present study, and they started to be instructed through genre-based writing pedagogy by the instructor. 


\subsection{The course and classroom practice}

ELL 103 and ELL 104 Writing courses were conceived as intensive courses taught over a period of two semesters, with the total of three contact hours in a week (in total, 14 weeks for each semester). Genre-based writing pedagogy prepared considering the students' academic needs and its teaching-learning cycle (deconstruction, joint construction and independent construction) was implemented as the instructional way of teaching writing to English language and literature students. The course included both conceptual and strategic content. Students learned about notions such as genre, register, discourse, audience and purpose as well as reading and writing strategies.

The main aims of the course were to expose participants to reading based writing and to analyse the differences in the rhetorical organisation and style in these texts in light of the ESP genre approach (Swales, 1990). There was deliberately no specific textbook for the course; two packs of selected materials (sample and literary texts for genres thought to be helpful in their academic study, and related activities) were prepared for two semesters by the researchers with other colleagues, who work in the same department. Students were supposed to read and study these materials to familiarise themselves with the main concepts of genre analysis and with professional academic prose within the literary context (see Appendix A and Appendix B for syllabi of two semesters).

The underlying pedagogical rationale was that genre analysis with the sample and literary texts would contribute to raising the students' genre awareness and would better prepare them to write their own essays in literary contexts. The first semester of the course was more technical when it was compared to the second semester. Students kept portfolios and 14 voluntary students wrote diaries about their writing experiences and their opinions about the course and the teacher from the beginning of the first semester. In the first semester, students focused on the analysis of the literary texts, which were also the examples of different genres. They had to analyse the texts from the aspects of both genre characteristics and their literary features in order to comprehend them in a very detailed way and thus, to be able to perform the related writing activity. On the other hand, they paid more attention to the genres and their characteristics while dealing with the texts rather than their literary features and analysis. The reason why they mostly studied the genres is that the primary aim of the course is to establish the genre knowledge and awareness, at the same time, as the additional purpose of the course; with literary analysis, they would prepare themselves for their future academic studies in the department or after the graduation.

In the second semester, students studied the sample texts for genres and they focused on the analysis of the different literary texts, which formed the background for the students' essay topics (parallel with the related genre). They also watched the short films of some of the literary texts at the end of the course. In that way, they 
concentrated on the text analysis in two ways: reading through genres and through a detailed literary text analysis.

\subsection{Research design}

The present study was designed as a case study because it sought to find out the developmental path the participants followed while they were taught writing with a genre-based approach. The lack of a priori assumptions about the results characterizes the research as an exploratory case study.

\subsection{Data collection and analysis}

Genre-based writing instruction was started to be implemented by the instructor and the qualitative data for the present study was obtained from several sources: (1) classroom observation and teacher's journal, (2) students' written texts (Portfolios), (3) students' diaries and, (4) interviews. By using multiple data collection tools, the researchers were better able to gather and analyse considerably more and different kinds of data than they would be able to use just one approach. Although all students kept portfolios including their essays from the beginning of the first semester, only 14 voluntary students wrote diaries about their writing experiences and their opinions about the course and the teacher. The teacher kept a journal including her observation and impressions about students' reactions towards the course, writing practices and the teacher during the both semesters. Interviews with five students were conducted once at the end of each semester. Collection of portfolios and diaries, and evaluation of the teacher's journal were finalized at the end of the first semester. The same procedures were also followed in the second semester. More detailed information about the data collection sources will be given separately as instruments for deeper understanding of the nature of data collection and to show how the collected data was analysed.

\subsubsection{Classroom observation and teacher's journal}

In this study, classroom observation was used as a research instrument, which provided the teacher's opinions and evaluations about the student's behaviours towards the teacher, course content, and classroom activities. Relevant comments under these themes were kept in a journal after each class. The teacher's observations and notes in the journal yielded regular and systematic data for the present study. The data in the journal were used to support the suggestions and results for the related parts of the study such as the students' metacognitive genre awareness, its effect on their analysis of academic and literary texts and their writing performance.

\subsubsection{Students' written texts (Portfolios)}

All of the students were informed about how to be engaged in portfolio keeping at the beginning of the course and assigned to keep portfolios including six essays for the first semester and eight essays for the second semester under the titles of related genres (see Appendix A and Appendix B). Portfolios contained students' first drafts, 
annotations on their first drafts and their second drafts in order. Students got consistent feedback for their writings in the first semester; however, in the second semester, they worked more independently and received mostly dialogic input from tutors and in group-discussions. Detailed feedback was provided by the instructor to see if the students' observations could suggest metacognitive awareness in relation to genre, and if so, what aspects of their analyses of academic texts and their essays supported these observations, and why. Portfolio analysis was conducted on writing samples of 14 students. 14 students' essays in their portfolios (who were also keeping diaries) were analysed and double checked by another colleague from the department to maintain more specific and elaborated information about the anticipated data for the study. Moreover, in order to understand the effect of metacognitive genre awareness on students' text analysis and writing performance, at the end of the second semester, the students' first and last essays in their portfolios were analysed. Researchers and another instructor from the department graded the students' essays. They were evaluated by using "ESL Composition Profile" (Muşlu, 2007, p. 129) (Appendix E) composed of eight categories. In short, multi-genre portfolios were evaluated for both students' achievement and progress in their own writings and they helped researchers to see how they deployed moves and steps in their writing and how their genre awareness became embedded in their stances over teaching process (portfolio usage as a self-assessment tool and as an alternative assessment tool).

\subsubsection{Students' diaries}

14 students volunteered to write diaries throughout the composition of each essay with the guidance of the week prompts for the first (Appendix C) and the second terms (Appendix D). Furthermore, the students wrote in their diaries about their own ideas or opinions, which they want to discuss with others, their writing experiences, their opinions about the course and the teacher. These comments were then compared to glean common themes and significant differences among students in light of the three categories of metacognitive awareness (Schraw \& Dennison, 1994, p. 460): 1) declarative awareness; 2) procedural awareness; and 3) conditional awareness. They became our categories of focus. After connecting the preliminary findings to the theoretical framework developed by Schraw and Dennison (1994), the researchers returned to the data to verify to what extent the findings could be supported by actual examples in the data. Besides, the coded data were cross-checked by a colleague who is interested in qualitative research and no major discrepancies were identified. Numbers were used in the excerpts so as not to reveal the participants' identities.

\subsubsection{Interview with Students}

Five of the 14 participants, which were randomly chosen, in the diary group were interviewed once at the end of each semester. The interviews were conducted in both Turkish and English to allow the students to express themselves more clearly and freely. The main purpose of the interviews was to learn the perceptions of the students about writing in general and the course content (genres, the sample and literary texts, etc.). The instructor conducted interviews with five of the 14 students 
keeping diaries since the data gathered would reveal more about what students think about the writing course and the course implementation period. The students were mainly asked about their feelings and ideas related to the writing and course content. The interviews were tape-recorded with the permission of the interviewees. Then, they were transcribed and translated into English when it was necessary.

In short, the findings are the outcome of discussion, reflection, and questioning. The interactive nature of data analysis provided the opportunity to explicitly articulate assumptions, question interpretations, and reflect possible different avenues of explanation, the kind of collaborative "reflexivity" that is so important for the trustworthiness of qualitative research (Jones, Torres, \& Arminio, 2006) and the validity of the interpretation (Guba \& Lincoln, 2005, p. 205).

\section{Results}

\subsection{Genre and metacognitive awareness}

In their study, Negretti and Kuteeva (2011) state that "genre awareness ties closely with metacognitive knowledge" (p. 96). They tried to trace "the development of students' genre awareness (Devitt, Reiff, \& Bawarshi, 2004) of research-based writing and interpret this process using the framework of metacognition theory" (Negretti \& Kuteeva, 2011, p. 96). They suggest that "the body of research on metacognition, its underlying processes, and its relevance for students' ability to learn and gauge performance" can provide knowledge about "how awareness of genre, discourse, and rhetoric comes into play when students read and write texts that are situated in different contexts" (p. 96).

As in the study of Negretti and Kuteeva (2011), in this study, the constructs and variables such as metacognitive genre awareness, students' analyses of academic texts and students' own writing were employed in the design, analysis and discussion of the study with some differences. Furthermore, this study was based on the examination of the students' writing process within the relation between genre awareness and metacognitive knowledge using the framework of metacognition theory.

Table 1 below demonstrates the development of metacognitive genre awareness based on Schraw and Dennison (1994) framework of metacognitive knowledge (Knowledge of Cognition: declarative knowledge, procedural knowledge and conditional knowledge). This table is a kind of summary of the students' expressions related to metacognitive genre awareness. 
Table 1. Development of metacognitive genre awareness based on Schraw and Dennison (1994) framework of metacognitive knowledge

\section{\begin{tabular}{ll} 
Student & Declarative knowledge (what) \\
\hline Student 1 & Week 2: parts of introduction
\end{tabular}}

Student 2 Week 3: specific relevance:

something, genre and introduction

Week 10: genre types

\section{Procedural knowledge (how)}

Week 3: Genres provide the ways of being professional

in writing (importance of techniques, sections of a text, rhetorical concepts).

Week 15: Knowing the genres makes the writing

process much clear.

Week 17: Genres provide the details about academic writing.

Week 21: Writing through genre is the analysis of an

analysis because attention should be paid on the different

techniques, styles and accordingly audience.

Week 14: Genres are the ways which show how

we write and what we write about.

Student 3 Week 3: characteristics of introduction

Week 5: genres, language,

structure

Week 15: Knowing genres make writing introduction

and organizing essay easier.

Student 4 Week 4: purpose, structure, language genres

about

Week 15: Reading through genres improves the ability

to write in English and the way of thinking toward

English in a positive manner.

Week 14: Knowing genres make you feel adequate and

Student 5 Week 4: relevance between genre and audience

Student 6 Week 5: features of introduction

Student 7 Week 5: relevance between social purposes and language

Student 8 Week 10: features of genres

exciting

Week 12: genres and their social purposes much confident in academic writing.

Week 22: Knowing details force to think a lot and deeper:

How to write, according to what, how to limit and how to develop.
Conditional knowledge (when)

\author{
Week 18: While reading \\ genres can provide detailed \\ understanding and analysis: \\ features, techniques, styles and content. \\ Week 20: Being eager to write can \\ depend on learning new things (genres). \\ Week 21: Argumentative type of writing \\ can change the point of view when
can \\ the author has some prejudice about a \\ topic.
}

Week 21: In other courses, it can be used (like research methods).

Week 22: When it is understood that

genres provide different ways for writing

something, more effective writing can be performed.

Week 17: Different features of

force to think while writing something

Week 20: Having categories are better for learning and practising writing because this provides variety.

\section{Week 16: When the topic is not}

detailed information of genres can make the writing activity easier.

: In other courses such as research methods and ethics, genres make the process easier.

Week 22: They can be used for text analysis to recognize the 
hidden messages and meanings.

Student 9 Week 10: language: adjectives,

Week 18: Writing and making analysis through genres are structure

useful to have a clear pattern to express and comprehend

strong feelings or opinions.

\section{Student Declarative knowledge (what)}

Student 10 Week 10: language and structure

Student 11 Week 12: relevance between genres and topics

Student 12 Week 10: definitions of genres and examples practicing

Week 20: different styles (subjectivity vs are necessary for

objectivity course)

Student 13 Week 5: learning strategies related to each genre
Week 15: Genres can be used to express feelings in a proper and structured way.

Week 19: Dealing with genres develops the ability of

understanding, analysing and presenting.

Week 15: Describing the importance of pronouns

and how the appropriate usage of them are related to

genre types

Week 16: Being aware of the importance of

biography

language and its components (like conjunctions) according to genres are useful for text organization.

Week 20: Knowledge of genres can be used in reading,

interpreting and analysing something related to literature.

Week 22: Knowing features of argumentative essays

can improve how you tell something about what you feel and this awareness can be used while supporting an idea and taking a stand.

Week 10: Being aware of genres is useful in expressing and reflecting yourself easily.

Week 15: It improves your English: grammar, sentence structure, vocabulary selection and conjunction usage.

and text structure, vocabulary selection and conjunctic
It provides the knowledge of how to start

writing and how to cover the topic in the light of features of genres.

Week 22: Genre knowledge provides both to
Week 20: The knowledge of genres is

useful when confusion is felt about how to write about something (the answer of in which topic I should do what?

Week 16: Experiencing and the different genres

being aware of their details and for the future career (example from

and autobiography writing)

Week 17: Knowledge of genres works

very well in analysing academic and

literary texts (for example in the

Week 15: Details of genres are able to stop myself in order not to be

the main idea.

Week 18: Variance gives opportunity to be aware of details of writing analysis.

Week 20: While writing about a topic the

genre awareness provides me to 


\section{writing process.}

Student 14 Week 10: genre structures, style and features

writing provide the

and make

Week 22: language, vocabulary and audience understand/ accept and have different point of views.

understand and cover the
Week 10: Knowing genres gives the feeling of being right place (not studying general topics but dealing with the

own field: literature and related genres).

Week 22: It can be helpful to change the way of thinking (first plan then act).
Week 22: Being guided and knowing the ways of thinking and

ability of expressing own ideas

me feel much comfortable. 
The comparison of students' reflections across two semesters provides that most of them acquired, at least, metacognitive awareness of the declarative type, for example, which genre-related concepts they think are important to understand and to write academic texts.

At the beginning of the course, notions such as parts of an essay, genre, purpose, language, and structure were mentioned by the students without specific connections. Towards the end of the course, however, students' metacognitive awareness (declarative) seemed to have focused on more specific features of academic communication, such as the relevance between genre and audience (Student 5 and Student 14), genres and their social purposes, their influence on language (Student 4, Student 7, Student 8, Student 9 and Student 10), genres and topics (Student 11), genre structures and different styles (Student 12 and Student 14). Similarly, most of the students showed metacognitive procedural awareness: In various ways, they attempted to think about how this knowledge could be applied to the analysis and the writing of academic texts. For instance, Students 3 mentioned how genre-relevant concepts could be used to think in a certain way when writing: "Knowing details force to think a lot and deeper: how to write, according to what, how to limit and how to develop". Furthermore, Student 14 mentioned: "It can be helpful to change the way of thinking (first plan then act)". Other students reflected on how some genre-relevant concepts could be applied stating that "Writing through genre is the analysis of an analysis because attention should be paid on the different techniques, styles and accordingly audience" (Student 2). For example, Student 9 and Student 10, reflecting on how to express feelings and opinions in their writings, said: "Writing and making analysis through genres are useful to have a clear pattern to express and comprehend strong feelings or opinions" (Student 9) and "Genres can be used to express feelings in a proper and structured way" (Student 10). In addition, Student 12 mentioned how the knowledge of a specific genre can be useful for supporting an idea: "Knowing features of argumentative essays can improve how you tell something about what you feel and this awareness can be used while supporting an idea and taking a stand". These examples showed that most of the students could move from declarative knowledge (what) to procedural knowledge (how) and they showed the metacognitive ability to apply the notions such as genre, social purpose and structure in different ways for different texts (conditional knowledge). For instance, Student 8 displayed knowledge of relevant notions such as the features of genres, and genres and their social purposes (Week 10 and Week 12). She understood the value of transferring this knowledge into specific strategies: "Knowing genres make you feel adequate and much confident in academic writing" (Week 14) and her second reflection in procedural knowledge shows a metacognitive shift. Concepts are now perceived through the questioning about their applications. For instance, she started to ask questions in the light of related notions about her writing (strategic aspects of writing) "Knowing details force to think a lot and deeper: how to write, according to what, how to limit and how to develop" (Week 22). Her reflections, in weeks 16 and 22 , represent conditional metacognitive genre awareness elaborating on the strategic 
significance of genre knowledge to deal with the writing in different contexts and interpret different types of academic texts (conditional awareness). We may put more light to our findings voicing her:

Excerpt 1: "When the topic is not exciting, detailed information of genres can make the writing activity easier" (Week 16) and

Excerpt 2: "In other courses, such as research methods and ethics, genres make the process easier" (Week 22);

Excerpt 3: "They can be used for text analysis to recognize the hidden messages and meanings" (Week 22).

These examples show the change in both general and genre related awareness as displayed in Table 1.

\subsection{Effects of metacognitive genre awareness on students' analysis of academic and literary texts}

Adequate information related to effects of metacognitive genre awareness on students' analysis of academic and literary texts is provided through the students' diaries, portfolios, interviews and teacher's classroom observation (notes in the journal).

Firstly, students' expressions produced during the interviews and in their diaries are examined to see the effects of metacognitive awareness of genre-relevant concepts on students' analysis of academic and literary texts. For instance, one student stated that

Excerpt 4: "Making genre analysis while reading a text showed me how to deal something about literature, help me how to interpret it and how to review and analyse it."

Excerpt 4 above explains the change of students' way of thinking about reading a piece of literature or an academic text. Other two excerpts below are also related to the changes in students' points of view as a result of the metacognitive awareness of genre-relevant concepts in analysis of academic and literary texts:

Excerpt 5: "Making text analysis and thinking in a detailed way changed me. I am searching for the hidden messages. While I am reading something, I ask questions to myself and I think about them. I don't just read it. Not knowing is happiness" (with an ironic tone).

Excerpt 6: "Text analysis is changed my point of view; learning new things (genres, stories...) make me eager to write”. “..... By detailed analysis, I could develop my thinking and decrease my prejudice. I had to consider different ways and different styles, and we experienced both different techniques and emotions. Interpreting about the texts was my favourite." 
The following two excerpts depicts the student's improvement in understanding that writing is a process requiring specific knowledge and not only including reading but also necessitating analysis:

Excerpt 7: “...learning technical knowledge about genres and making literary analysis are very helpful to understand the process as a whole."

Excerpt 8: "I can manage to make comparisons between genres, and this helps me in both writing and analysing something. For example, in argumentation, I have learned to take a stand and before having it I try to understand and evaluate the both sides. In text responses, I had difficulties (especially film review: you shouldn't tell the whole story but you have to get the reader's attention. It is hard to keep it on balance)."

The structure of the design generated with the genre-based writing instruction was also appreciated by the students in affecting their reading habits as indicated in the following two excerpts:

Excerpt 9: "Short stories that we studied provided background information (mostly on feelings and understanding of the topic). Reading literary texts with genres is perfect; it is like using an elevator instead of the stairs"

Excerpt 10: “... the most favourite thing for me was the processing way of the course: reading, writing, literature, detailed analysis, interpretation, etc.”

The teacher's observation and notes also indicated that students could make more specific and detailed analysis while they were dealing with the reading of the texts in the second semester. For example:

Excerpt 11: "During this term, the teacher asked the related analysis questions to the students as guidance for them, and most of the time, the teacher started the discussion for making the analysis clearer for the students" uttered by the teacher at the end of the first semester, and she mentioned about the change in students' responsiveness in the third week of the second semester as follows:

Excerpt 12: "Students are very eager to perform the pre-reading activities, this situation make them much more motivated and ready for the rest of the activities (analysis and writing)"; and the teacher wrote the following note related to the students' performances in analysis of texts in the seventh week of the second semester:

Excerpt 13: 'The students' answers to the comprehension and analysis questions and their interpretations related to the both reading texts and the texts which they will write about are much sophisticated and creative."

Table 2 below shows the differences related to the content, organization, discourse markers, vocabulary, sentence variety, language use, spelling and mechanics (within the frame of the related genre) between the students' first and last essays. 
Table 2. The Differences (within the frame of the related genre) between the Students' First and Last Essays

\begin{tabular}{|c|c|c|c|c|c|c|c|c|c|c|c|c|c|c|c|c|c|c|c|c|c|c|c|c|c|c|c|c|c|c|c|c|c|c|}
\hline \multirow{2}{*}{ 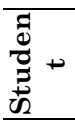 } & \multirow{2}{*}{ 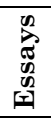 } & \multicolumn{4}{|c|}{ Content } & \multicolumn{4}{|c|}{ Organization } & \multicolumn{4}{|c|}{$\begin{array}{c}\text { Discourse } \\
\text { Markers }\end{array}$} & \multicolumn{4}{|c|}{ Vocabulary } & \multicolumn{4}{|c|}{$\begin{array}{c}\text { Sentence } \\
\text { Variety }\end{array}$} & \multicolumn{4}{|c|}{$\begin{array}{c}\text { Language } \\
\text { Use }\end{array}$} & \multicolumn{4}{|c|}{ Spelling } & \multicolumn{4}{|c|}{ Mechanics } & \multirow{2}{*}{$\begin{array}{c}\text { Total } \\
100 \\
\end{array}$} \\
\hline & & 30 & 26 & 21 & 16 & 10 & 8 & 5 & 2 & 15 & 12 & 8 & 4 & 15 & 12 & 8 & 4 & 10 & 8 & 5 & 2 & 10 & 8 & 5 & 2 & 5 & 4 & 3 & 2 & 5 & 4 & 3 & 2 & \\
\hline \multirow{2}{*}{-} & 1 & & 26 & & & 9 & & & & & 12 & & & & 12 & & & & 8 & & & & 8 & & & & 4 & & & & 4 & & & 83 \\
\hline & 2 & & 24 & & & & 8 & & & & 10 & & & & 11 & & & & 7 & & & & 8 & & & & 4 & & & & 4 & & & 76 \\
\hline \multirow{2}{*}{ N } & 1 & 27 & & & & 9 & & & & 13 & & & & 13 & & & & 9 & & & & 9 & & & & & 4 & & & & 4 & & & 92 \\
\hline & 2 & 29 & & & & 9 & & & & 13 & & & & 13 & & & & 9 & & & & 9 & & & & & 4 & & & & 4 & & & 94 \\
\hline \multirow{2}{*}{$\infty$} & 1 & & 24 & & & & 6 & & & & 9 & & & & 10 & & & & 7 & & & & 6 & & & & & 3 & & & & 3 & & 68 \\
\hline & 2 & & 23 & & & & & 5 & & & & 8 & & & & 8 & & & & 5 & & & 6 & & & & & 3 & & & & 3 & & 61 \\
\hline \multirow{2}{*}{$\nabla$} & 1 & & 26 & & & & 8 & & & & 12 & & & 13 & & & & & 8 & & & & 8 & & & & 4 & & & & & 3 & & 82 \\
\hline & 2 & 27 & & & & 9 & & & & 13 & & & & 13 & & & & 9 & & & & 9 & & & & & 4 & & & & 4 & & & 88 \\
\hline \multirow{2}{*}{10} & 1 & & & 20 & & & & 5 & & & 12 & & & & & 8 & & & & 5 & & & 8 & & & & 4 & & & & & 3 & & 65 \\
\hline & 2 & & 26 & & & & 8 & & & & 12 & & & & & 8 & & & & 6 & & & & 7 & & & 4 & & & & 4 & & & 75 \\
\hline \multirow[b]{2}{*}{0} & 1 & & 24 & & & & 6 & & & & 9 & & & & 9 & & & & 6 & & & & 6 & & & & & 3 & & & & 3 & & 66 \\
\hline & 2 & 28 & & & & & 8 & & & & 10 & & & & 12 & & & & 7 & & & & 7 & & & & & 3 & & & & 3 & & 78 \\
\hline - & 1 & & & & 16 & & & 5 & & & & 8 & & & & 8 & & & & 5 & & & & 5 & & & & 3 & & & & 3 & & 53 \\
\hline 5 & 2 & & 23 & & & & 6 & & & & & 8 & & & 9 & & & & 6 & & & & 6 & & & & & 3 & & & & 3 & & 64 \\
\hline & 1 & & & & & & & & & & The & ssay & do & es n & tinc & ude & his & own & ord & anc & id & & & & & & & & & & & & & 0 \\
\hline$\infty$ & 2 & & 25 & & & & 7 & & & & 10 & & & & 11 & & & & 7 & & & & 7 & & & & 4 & & & & 4 & & & 75 \\
\hline 0 & 2 & 27 & & & & & 8 & & & & 11 & & & & 11 & & & & 8 & & & & 8 & & & & 4 & & & & 4 & & & 81 \\
\hline 0 & 1 & & 26 & & & & 8 & & & & 11 & & & & 10 & & & & 7 & & & & 7 & & & & & 3 & & & & 3 & & 74 \\
\hline$\tau$ & 2 & 27 & & & & & 8 & & & & 11 & & & & 12 & & & & 8 & & & & 8 & & & & 4 & & & & 4 & & & 82 \\
\hline & 1 & & 26 & & & & 6 & & & & 10 & & & & 9 & & & & 7 & & & & 7 & & & & 4 & & & & & 3 & & 72 \\
\hline$\exists$ & 2 & 27 & & & & 9 & & & & & 10 & & & & 11 & & & & 8 & & & & 8 & & & & 4 & & & & & 3 & & 80 \\
\hline N & 1 & & 26 & & & & 8 & & & & 11 & & & & 11 & & & & 7 & & & & 8 & & & & & 3 & & & & 3 & & 77 \\
\hline$\stackrel{\sim}{\sim}$ & 2 & 28 & & & & 9 & & & & 13 & & & & 13 & & & & 9 & & & & 9 & & & & & 4 & & & & 4 & & & 89 \\
\hline$\infty$ & 1 & & & & 16 & & 8 & & & & 10 & & & & 10 & & & & 7 & & & & 6 & & & & 4 & & & & & 3 & & 64 \\
\hline-1 & 2 & 27 & & & & & 8 & & & & 12 & & & & 12 & & & & 8 & & & & 8 & & & & 4 & & & & 4 & & & 83 \\
\hline & 1 & & & 18 & & & & 5 & & & & 5 & & & & 8 & & & & 3 & & & & 3 & & & & 3 & & & & & 2 & 47 \\
\hline- & 2 & & 23 & & & & 7 & & & & 9 & & & & 9 & & & & 6 & & & & 7 & & & & & 3 & & & & & 2 & 67 \\
\hline
\end{tabular}


When the students' scores are analysed considering each category of the "ESL Composition Profile", most of the students seem to move their ability up in the scale, especially in the content category. The positive manner in the content category of the scale is very meaningful from the aspect of genre analysis and producing appropriate writing pieces for two reasons: first, it is the backbone of the essay writing in general and thus, it covers the biggest part and includes everything, which is also necessary for a proper essay (introduction, development and conclusion). Second, while analysing a text, students should understand the content and its related genre and while they are writing they should also arrange their essay content according to the related genre. In order to be able to comprehend and write appropriately they should both analyse and compose contents, which carry the specific features of the supposed genre. The course content in particular, in this study, requires adequate and efficient text analysis (reading and analysis of the course materials) because if the students can be successful in understanding and analysing the text then they can manage to perform appropriate writing pieces within the frame of targeted genre. This is how the portfolio analysis provides data for the students' progress both in their text analysis and writing performance.

\subsection{Effects of metacognitive genre awareness on students' writing performance}

Table 2 above presents the comparison of the 14 students' first and last essays according to the ESL Composition Profile. During the evaluation of the students' texts all of the categories of the scale were taken into consideration according to the characteristics of each genre. For example, students' first essays were written in the form of recount writing and the last ones were written in text responses (interpretation). Students' essay scores show that 12 students out of 14 succeeded to increase their ability in writing based on a genre acquisition. Even if writing text responses (interpretation) are generally seen more difficult than writing recounts, they were able to get higher scores from the last essays. When the students' scores are analysed considering each category of the scale, they indicate that most of the students moved their ability up in the scale especially in the content category.

In addition, the teacher's notes related to the essays in the portfolios present explanatory data for students' development in writing performance. The first essays do not have sufficient introductions or thesis statements and most of them do not have effective conclusions. With a specific emphasis on these sections, in general essay writing and genre related writing, they came to be more aware of and paid attention to these parts. In the last examples, the difference and progress can be observed in that sense and the teacher's notes also support this change. Some examples from the teacher's notes are given below:

Excerpt 14: "an insufficient introduction and conclusion (with very superficial thoughts and opinions about the text)" for the first and the last essay of the student, the teacher mentioned: 
Excerpt 15: "More effective introduction with enough information about the story and her own feelings and a much more effective conclusion."

Two notes indicating another student's improvement in producing well-written texts are as follows:

Excerpt 16: "Good introduction but it can be developed. It is a bit inconsistent" stated by the teacher for the first essay of the student, and for her last essay, the teacher mentioned:

Excerpt 17: "It is a very good essay with the telling of the story and giving his own feelings. Also, he gives some examples and quotes from some other fictional stories."

The next excerpt is the note related to Student 8 in Table 2. It is seen in Table 2 that Excerpt 18: "The essay does not include his own words and ideas". The student has made use of other sources when writing, instead of creating his authentic work.

However, the second note related to his last essay displayed that the student developed the writing ability in using others' work without making plagiarism during the writing activity and adding appropriately his own feelings and ideas to his writing.

Excerpt 19: "There are some quotations from other sources, but for this time they are limited and with references. He also added his own feelings and opinions."

To sum up, in a genre-based writing instruction, the positive results in the content category of the essay evaluation (also in the other related categories) and the general increase in students' essay scores can be considered as the evidence for the students' improvement in writing performance.

\section{Discussion}

At the very beginning of the semester, most of the students were not sure about their stances toward writing (positive or negative). In their diaries, they generally preferred to tell about their daily routines. After a few weeks, instead of daily routines, they started to mention other people, other courses, literature as their own study field, their academic interests, some concepts such as friendship, egoism, selfishness, and women's rights and about movies and books. While they were writing about these kinds of subjects freely, at the same time, they were supposed to write about their feelings or opinions about the teacher, their progress and the course itself: topics, activities, genres and so on. They were also required to write in their diaries with the guidance of the week prompts for the first and the second terms.

As acknowledged previously, few weeks later, they started to refer to their progress in most of the aspects of writing, and while they were doing this, their manner was more positive and they began to gain self-confidence in writing about anything. In their diaries and interviews, they declared such feelings like 
Excerpt 20: "I think I improved myself a lot. I saw an essay from past (from the beginning of the first semester) and compared it with the current writings. Both my grammar and the content of the essays are very different. I feel better in writing now."

The students' improvement in structure and content fields is mentioned by the following text:

Excerpt 21: "I couldn't write anything, I had some knowledge from prep-class but it was not enough. I checked my file and I saw that I wrote only three sentences for the introduction but now I can write more than five sentences. In addition, their content developed. Even if I can't speak, I can express myself through writing"

Other two examples related to the progress and change in the students' language usages are as follows:

Excerpt 22: “...... getting feedback is good; through writing I can develop my English; ... with the help of this course, I learned how to start writing, how I should be careful about the things while writing something, I can now stop and limit myself in order not to be remote from the main idea."

Excerpt 23: "I like writing and the course. It improved my grammar and vocabulary. I had difficulties in vocabulary selection; I still have but I feel the change positively. In the beginning I would say I didn't like writing", "Previously I could write few sentences but now I can write paragraphs; I know how to write an introduction and organize an essay."

The following two statements are related to changes in the students' self confidence in writing.

Excerpt 24: "I didn't like writing before, I cannot say I like it very much right now but my attitude is not so bad", "I was afraid of writing academic texts, I think I improved myself because I feel much confident now", "Even if I don't like the topic, I can manage to write something about it."

Excerpt 25: "I didn't like writing because I didn't have self-confidence in writing. I like watching something, but not reading or writing. Here we both read and write, the teacher encouraged us and I started to read and write something and I started to like doing it. During summer, also, I will continue to write something."

Students, as could be understood from their short and non-specific sentences, appeared to be at superficial level in expressing and evaluating themselves at the beginning of the study. However, they turned out to be more competent in analysing their own improvement in writing. When we consider the sentences they created with details such as positions and their reasons, causes and their effects or vice versa, definitions and examples, we may say that there was an increase in the students' selfawareness.

The change in both general and genre related awareness was more clearly observed from the expressions uttered by the students during and at the end of the second 
semester. The comparison of and differences in the students' past and present writing habits can be detected in the following statements:

Excerpt 26: "There is a huge difference when I compare my current writing to the beginning. I am still stressful but I can see the positive changes. For example, I couldn't write two sentences in an hour but now I can express myself, my ideas with longer sentences."

Excerpt 27: "In the past, I thought how the other students can write pages in English but now I can also manage to write about something with the help of knowledge I have"

Excerpt 28: "I understood that my writings previously were like free writing thus I felt like I was lost in ideas."

Excerpt 29: "I thought 'Essay is essay' in the beginning and everybody could write an essay. It was not an essay actually; it was like free writing. However, we are literature students and we should know the necessities and details of academic writing."

Students also indicated the positive change in their points of view as a result of the course design:

Excerpt 30: "When I think about something I can express it much more easily. I have less stress because before I would think how I should start to write, what I have written about and etc." and "In introduction, I know how to start, what to mention and how I limit my writing."

Excerpt 31: "I think writing is more important than the other courses because it develops not only the ability of 'expressing' but also the other abilities like comprehending, analysing etc."

Excerpt 32: “.... after taking this course I feel myself as if I grew up.”

The data gathered from the students provided evidence for their progress and positive change in their ability to write, in genre awareness, in English language and in their attitude toward writing. Moreover, the teacher's weekly notes about the courses showed that even if they felt confused in the beginning they managed to cover the key points in time. The teacher mentioned the followings

Excerpt 33: "Students cannot give the exact reasons of why they are dealing with genres in such a detailed way" in the fourth week.

Excerpt 34: "Students start to realize the differences between the genres and their features; they can realize the progress, but they don't manage to explain it in a detailed way" in the eighth week; yet when we look at the last week of the semester, we see that

Excerpt 35: "They are not totally aware of the writing process and the genres, nevertheless, they can feel the difference and try to understand the details" at the last week of the first semester. 
In addition, there were some notes related to their participation and approach to the course and course content such as

Excerpt 36: "They had difficulty to understand the difference between the 'recount' and 'narrative' genres; they need to remember the features and samples of the recounting" in the sixth week;

Excerpt 37: "They liked the 'exemplum' very much; in my opinion, the text ('The Wife of Bath' from Chaucer) has an effect on this manner" in the seventh week; and

Excerpt 38: "They stated that they see the importance of auto-biography in this course; they have never thought about the genre in that way (they felt themselves more important)" in the thirteenth week.

During the second semester, the teacher observed a higher level of self-awareness, genre-awareness and attention to the course. This study tried to explore how English Language and Literature students developed their genre awareness and knowledge, and writing competence as they were engaged in systematically designed genre-based writing tasks that incorporated essay writing. Findings demonstrate that a genrebased approach to writing based on the three phases of the teaching-learning cycle has created a positive impact on the participants in terms of understanding the process as a whole. Indeed, most of the students gained control over the key features of the required genres, and they expressed their positive feelings towards the approach.

\section{Conclusions}

It is our hope that valuable implications for designing syllabi and in-class activities for writing classrooms are offered by the present study in terms of practice and pedagogy in foreign language writing. This study has attempted to suggest some of the ways that genre can be of considerable theoretical and practical relevance for preparing students to write in L2 classrooms. As Hyland (2007) stated in a very clear and accurate way

... a well-formulated theory of how language works in human interaction has become an urgent necessity in the field of teaching second language writing. Genre pedagogies are a major response to this need, providing teachers with a way of understanding how writing is shaped by individuals making language choices to achieve purposes in social contexts ( $p$. 163).

At the very beginning of the study (the beginning of the first semester), students have had an uncertain view of a genre and by the implementation of the genre-based writing instruction they have begun to cover a more informed understanding of how text might be formed and structured to meet contextual needs. This development has also affected their improvement in contextual analysis skills and they can continue to apply them in their actual practice. In this sense, it seems that rhetorical reading is extremely important in teaching writing to students in their first year at English 
Language and Literature Department and it should be integral to building their ability to write in different genres.

Furthermore, students' comments in the interviews demonstrated that the analysis of the sample texts was very useful in helping them see how the linguistic resources they had known at a receptive level were actually used to achieve a goal in a real-life situation. In other words, genre-based pedagogic tasks have provided a salient link between form and function. This link enables students to have an initial framework for production.

Results showed that the students made clear gains in some aspects of their writing performance, as well as in their awareness and perceptions of their genre knowledge development. The analysis demonstrated that they became more able to control the degree of formality in response to the given context and make more appropriate linguistic choices to respond to the reader and to achieve the specific goal of the given task.

Another important point to mention is the relationship among genres, choices, and constraints. This was pointed out that there was a criticism that genre-based pedagogies might constrain writers' creativity through prescriptivism and that genre teachers may accommodate students to the model of the dominant discourse by simply encouraging them to write as they were taught. However, this argument can be levelled at almost all teaching approaches. Obviously the dangers of a static, decontextualized pedagogy are very real if teachers fail to acknowledge variation and apply what Freedman (1994) calls "a recipe theory of genre" (p. 46). Learning about genres does not preclude critical analysis, but in fact, provides a necessary basis for critical engagement with cultural and textual practices. Therefore, the present study follows a kind of genre-based writing instruction, which was formed according to the students' academic needs and focuses on developing students' genre- awareness.

One of the important and difficult points which should be considered while implementing genre-based writing instruction in ESP environment is to introduce many well-written sample reading texts which contain the features of the specific text-types into their own classroom. As discussed before, one of the difficulties faced by students when they develop writing skills was that they lacked the knowledge of the text-type in terms of language features and text features; therefore, they did not know how to turn their ideas into an intelligible text. Thus, while organising the design and materials of the course, paying enough attention to selection of the texts which serve as a model for students should be given importance as much as the implementation and practice phases of these texts.

Another difficulty that might be faced during the implementation of a genre-based writing instruction is that the instructor should always be aware of the teachinglearning cycle. According to its stages, students' reactions should be taken into consideration. Teachers should resort to the flexibility of the genre-based approach. It means that although genre-based approach is based on the three phases of the teaching-learning cycle, it is possible for some capable students to move further. 
Within these terms, managing these purposes is very difficult for an instructor teaching in a crowded classroom as was the case in this study. For example, a crowded classroom made difficult to read and analyse even the sample texts. At the beginning of the semester, sample reading texts were given as homework and the analyses were done in the classroom for saving time. However, the problem was that most of the students came to the classroom without reading the texts. This situation inhibited the effective analysis of the texts in the classroom. In order to solve this problem, the instructor started to read the texts in the classroom but, still, it was time consuming; and even if some students liked reading in the classroom the rest felt bored. As a last attempt, the instructor assigned students to read the texts at home and showed short movies of the stories in the classroom which seemed to work better. Furthermore, following the portfolios and giving feedback were very difficult for the instructor considering the number of the students in the classroom.

However, despite all, at the end of the course, most of the students could transform their genre knowledge from a receptive level to a productive level after a careful and detailed implementation. When genre-based tasks are systematically designed, writers can gradually develop a range of linguistic/rhetorical choices to make and perform a certain social action in a socially appropriate manner.

In addition, this study aimed to explain how the participants developed their genre awareness and writing competence as they engaged in a range of genre-based tasks in a foreign language context. The study had its own limitations.

This study is limited to a sample of first year students from English Language and Literature Department at a state university and their writing skills during the first and second terms. Students' age, sex and educational background were not taken into consideration because convenient sampling had to be used in this research. This study only examined one group without reference to a comparison group. Therefore, even though the students' writing showed an improvement during two semesters, it is hard to conclude that the improvement is solely derived from the instruction. Future studies would thus need to use two different treatment groups and compare the achievement of these two groups.

This study is also limited to genres which have been thought to be useful for students' academic studies, and activities were suited to the objectives of genre-based writing instruction and they were geared to serve the literature students' academic needs. A further study might focus on students' development on a long term basis in other writing situations.

\section{References}

Azevedo, R., \& Whiterspoon, A. M. (2009). Self-regulated use of hypermedia. In A. Graesser, J. Dunlosky, \& D. Hacker (Eds.), Handbook of metacognition in education (pp. 319-339). Mahwah, NJ: Erlbaum.

Beaufort, A. (2007). College writing and beyond: A new framework for university writing instruction. Logan, UT: Utah State University Press. 
Bereiter, C., \& Scardamalia, M. (1987). The psychology of written composition. Hillsdale, NJ: Lawrence Erlbaum.

Breetvelt, I., Van den Bergh, H., \& Rijlaarsdam, G. (1994). Relations between writing processes and text quality: When and how? Cognition and Instruction, 12, 103-123. http://www.jstor.org/stable/3233677

Brown, A. (1987). Metacognition, executive control, self-regulation, and other more mysterious mechanisms. In F. Weinert, \& R. Kluwe (Eds.), Metacognition, motivation, and understanding (pp. 65-116). Hillsdale, NJ: Erlbaum.

Cheng, A. (2007). Transferring generic features and recontextualizing genre awareness: Understanding writing performance in the ESP genre-based literacy framework. English for Specific Purposes, 26(3), 287-307. https://doi.org/10.1016/j.esp.2006.12.002

Devitt, A., Reiff, M. J., \& Bawarshi, A. (2004). Scenes of writing: Strategies for composing with genres. New York, NY: Longman.

Dunlosky, J., \& Metcalfe, J. (2009). Metacognition. Thousand Oaks, CA: Sage.

Flavell, J.H. (1987). Speculations about the nature and development of metacognition. In F. Weinert, \& R. Kluwe (Eds.), Metacognition, motivation, and understanding (pp. 21-29). Hillsdale, NJ: Erlbaum.

Flavell, J. H. (1979). Metacognition and cognitive monitoring: A new era of cognitivedevelopmental inquiry. American Psychologist, 34, 906-911. https://doi.org/10.1037//0003066X.34.10.906

Flower, L., \& Hayes, J. R. (1980). The cognition of discovery: Defining a rhetorical problem. College Composition and Communication, 31, 21-32. http://www.jstor.org/stable/356600?origin=JSTOR-pdf

Flower, L., \& Hayes, J. R. (1981). A cognitive process theory of writing. College Composition and Communication, 32, 365-387. http://dx.doi.org/10.2307/356600

Freedman, A. (1994). "Do as I say?": The relationship between teaching and learning new genres. In A. Freedman \& P. Medway (Eds.), Genre and the new rhetoric (pp. 191-210). London: Taylor \& Francis

Gombert, J. E. (1993). Metacognition, metalanguage and metapragmatics. International Journal of Psychology, 28, 571-580. https://doi.org/10.1080/00207599308246942

Guba, E. G., \& Lincoln, Y. S. (2005). Paradigmatic controversies, contradictions, and emerging confluences. In N. K. Denzin, \& Y. S. Lincoln (Eds.), The Sage handbook of qualitative research (pp. 191-215). Thousand Oaks, CA.: Sage Publications Ltd.

Hacker, D. J., Keener, M. C., \& Kircher, J. C. (2009). Writing is applied metacognition. In D. J. Hacker, J. Dunlosky, \& A. C. Graesser (Eds.), Handbook of metacognition in education (pp. 154-172). New York, NY: Routledge.

Hyland, K. (2004). Disciplinary discourses. Ann Arbor, MI: University of Michigan Press.

Hyland, K. (2007). Genre pedagogy: Language, literacy and L2 writing instruction. Journal of Second Language Writing, 16, 148-164. http://dx.doi.org/10.1016/j.jslw.2007.07.005

Jacobs, J. E. \& Paris, S. G. (1987). Children's metacognition about reading: Issues in definition, measurement, and instruction. Educational Psychologist, 22, 255-278. http://dx.doi.org/10.1207/s15326985ep2203\&4_4

Jones, S. R., Torres, V., \& Arminio, J. (2006). Negotiating the complexities of qualitative research in higher education: Fundamental elements and issues. New York, NY: Routledge.

Johns, A. M. (2011). The future of genre in L2 writing: Fundamental, but contested, instructional decisions. Journal of Second Language Writing, 20, 56-68. http://dx.doi.org/10.1016/j.jslw.2010.12.003 
Kay, H., \& Dudley-Evans, T. (1998). Genre: What teachers think. ELT Journal, 52(4), 308-314. https://doi.org/10.1093/elt/52.4.308

Kellogg, R. (1994). The psychology of writing. New York: Oxford University Press.

Martin, J. R. (1993). A contextual theory of language. In B. Cope, \& M. Kalantzis (Eds.), The powers of literacy. A genre approach to teaching writing. London: The Falmer Press.

Martin, J. R. (2009). Genre and language learning: A social semiotic perspective. Linguistics and Education, 20, 10-21. https://doi.org/10.1016/j.linged.2009.01.003

Muşlu, M. (2007). Formative evaluation of a process-genre writing curriculum at Anadolu University School of Foreign Languages (Unpublished doctoral dissertation). Anadolu Üniversitesi, Eskişehir.

Myhill, D., \& Jones, S. (2007). More than just error correction: Student's perspectives on their revision processes during writing. Written Communication, 24, 323-343. https://doi.org/10.1177/0741088307305976

Negretti, R. (2009). Metacognitive awareness in developmental writing students. (Unpublished doctoral dissertation). University of Hawai'I, Manoa.

Negretti, R., \& Kuteeva, M. (2011). Fostering metacognitive genre awareness in L2 academic reading and writing: A case study. Journal of Second Language Writing, 20, 95-110. http://dx.doi.org/10.1016/j.jslw.2011.02.002

Serra, M. J., \& Metcalfe, J. (2009). Effective implementation of metacognition. In D. J. Hacker, J. Dunlosky, \& A. C. Graesser (Eds.), Handbook of metacognition and education (pp. 278298). New York, NY: Routledge.

Schraw, G. (1998). Promoting general metacognitive awareness. Instructional Science, 26, 113125. https://doi.org/10.1023/A:1003044231033

Schraw, G., \& Dennison, R. S. (1994). Assessing metacognitive awareness. Contemporary Educational Psychology, 19, 460-475. https://doi.org/10.1006/ceps.1994.1033

Schraw, G., \& Moshman, D. (1995). Metacognitive theories. Educational Psychological Review, 7, 351-371. https://doi.org/10.1007/BF02212307

Swales, J. M. (1990). Genre analysis: English in academic and research settings. Cambridge: Cambridge University Press.

Swales, J. (2004). Research genres. New York: Cambridge University Press.

Swales, J., \& Feak, C. (2000). English in today's research world: A writing guide. Ann Arbor, MI: University of Michigan Press.

Swales, J. M., \& Feak, C. B. (2004). Academic writing for graduate students: Essential tasks and skills (2nd ed.). Ann Arbor, MI: University of Michigan Press.

Tribble, C. (1996). Writing. Oxford: Oxford University Press.

Veenman, M., Wilhelm, P., \& Beishuizen, J. J. (2004). The relation between intellectual and metacognitive skills from a developmental perspective. Learning and Instruction, 14, 89109. http://dx.doi.org/10.4236/psych.2013.47084

Willingham, D. T. (2009). Why don't students like school? A cognitive scientist answers questions about how the mind works and what it means for the classroom. San Francisco, CA: Jossey-Bass.

Yayli, D. (2011). From genre awareness to cross-genre awareness: A study in an EFL context. Journal of English for Academic Purposes, 10(3), 121-129. https://doi.org/10.1016/j.jeap.2011.02.001

Zimmerman, B. J., \& Schunk, D. H. (2001). Self-regulated learning and academic achievement: Theoretical perspectives. Mahwah, NJ: Erlbaum. 


\section{Appendix A. Syllabus of the First Term}

Portfolio Assignments: 14\%

Midterm: 26\%

Final: $60 \%$

\begin{tabular}{|c|c|c|}
\hline Date & Content & Assignments \\
\hline Week 1 09/19 & $\begin{array}{l}\text { Introduction to the course. Detailed information about the goals and } \\
\text { objectives of the course, content of the syllabus, and assessment of } \\
\text { the course }\end{array}$ & \\
\hline Week 2 10/26 & Essay Writing + Paraphrasing, giving reference, plagiarism & \\
\hline Week 3 10/03 & Literary Genres + Text Genres (Genre+ Register+ Discourse) & \\
\hline Week 4 10/10 & (A Recount of Boy Waving Goodbye to His & \\
\hline Week 5 10/17 & (The Tell-Tale Heart by Edgar Allan Poe) & The $1^{\text {st }} \mathrm{HW}$ is to be assigned \\
\hline Week 6 10/24 & $\begin{array}{l}\text { (Shooting An Elephant by George Orwell) } \\
\text { (Yellow Wallpaper by Charlotte Perkins Gilman) }\end{array}$ & $\begin{array}{c}\text { The } 2 \mathrm{nd} \mathrm{HW} \text { is to be } \\
\text { assigned } \\
\text { The } 1^{\text {st }} \mathrm{HW} \text { is to be collected }\end{array}$ \\
\hline Week 7 10/31 & (The Wife of Bath's Tale by Chaucer) & $\begin{array}{l}\text { The 3rd HW is to be assigned } \\
\text { The 2nd HW is to be } \\
\text { collected }\end{array}$ \\
\hline Week 8 11/07 & (Lottery by Shirley Jackson) & \\
\hline Week 9 & Midterm Week- No class & \\
\hline Week 10 11/21 & \begin{tabular}{|l}
$\begin{array}{l}\text { Anecdote } \\
\text { Death }\end{array}$ \\
$\begin{array}{c}\text { (Excerpt from The Crucible by Arthur Miller \& } \\
\text { (The Necklic) }\end{array}$ \\
\end{tabular} & $\begin{array}{l}\text { The 4th HW is to be assigned } \\
\text { The 3rd HW is to be collected }\end{array}$ \\
\hline Week 11 11/28 & Autobiography (Goodbye to All That by Robert Graves) & $\begin{array}{l}\text { The 5th HW is to be assigned } \\
\text { The 4th HW is to be collected }\end{array}$ \\
\hline Week 12 12/05 & $\begin{array}{l}\text { (A Childhood: The Biography of A Place by Harry } \\
\text { Crews) }\end{array}$ & $\begin{array}{l}\text { The } 6 \text { th HW is to be assigned } \\
\text { The 5th HW is to be collected }\end{array}$ \\
\hline Week 13 12/12 & $\begin{aligned} \text { Historical Recount and Account } & \text { (Attack: The Coral Sea Becomes a } \\
& \text { watery Grave Yard) }\end{aligned}$ & $\begin{array}{l}\text { The 7th HW is to be assigned } \\
\text { The 6th HW is to be collected }\end{array}$ \\
\hline Week 14 12/16 & & Portfolios are to be collected \\
\hline
\end{tabular}




\section{Appendix B. Syllabus of the Second Term}

\begin{tabular}{|c|c|c|}
\hline Date & Content & Assignments \\
\hline Week 1/ 09-13 Feb. & Introduction to the course. & \\
\hline Week 2/ 16-20 Feb. & $\begin{array}{l}\text { Essay Writing + Paraphrasing, giving reference, } \\
\text { plagiarism }\end{array}$ & \\
\hline Week 3/ 23-27 Feb. & Introduction to Explanation & \\
\hline Week 4/ 02-06 March & $\begin{array}{l}\text { Explanation (Sequential Explanation) } \\
\text { (A Dill Pickle by Katherine Mansfield) }\end{array}$ & The $1^{\text {st }} \mathrm{HW}$ is to be assigned \\
\hline Week 5/ 09-13 March & $\begin{array}{l}\begin{array}{l}\text { Explanation (Factorial Explanation) } \\
\text { (Charles by Shirley Jackson) }\end{array} \\
\end{array}$ & $\begin{array}{l}\text { The 2nd HW is to be } \\
\text { assigned }\end{array}$ \\
\hline Week 6/ 16-20 March & $\begin{array}{l}\text { Explanation (Consequential Explanation) } \\
\text { (True Love by Isaac Asimov) }\end{array}$ & $\begin{array}{c}\text { The } 3 \text { rd HW is to be } \\
\text { assigned }\end{array}$ \\
\hline Week 7/ 23-27 March & Midterm Week- No class & \\
\hline Week 8/ 30 M.-3 April & Introduction to Arguments & \\
\hline Week 9/ 06-10 April & $\begin{array}{l}\text { Arguments (Analytical/Exposition) } \\
\text { (A Rose for Emily by William Faulkner) }\end{array}$ & $\begin{array}{l}\text { The 4th HW is to be } \\
\text { assigned }\end{array}$ \\
\hline Week 10/ 13-17 April & $\begin{array}{l}\text { Arguments (Discussion) } \\
\text { (Open Window by Saki) }\end{array}$ & $\begin{array}{l}\text { The 5th HW is to be } \\
\text { assigned }\end{array}$ \\
\hline Week 11/ 20-24 April & Introduction to Text Responses & \\
\hline $\begin{array}{|llll|}\text { Week } & 12 / & 27 & \text { April-1 } \\
\text { May } & & & \end{array}$ & $\begin{array}{l}\begin{array}{l}\text { Text Responses (Personal Response/Critical } \\
\text { Response) } \\
\text { Ross) }\end{array} \\
\text { (The Painted Door by Sinclair }\end{array}$ & $\begin{array}{l}\text { The 6th HW is to be } \\
\text { assigned }\end{array}$ \\
\hline Week 13/ 04-08 May & $\begin{array}{l}\text { Text Responses (Review) } \\
\text { (Watching of the film and discussion) }\end{array}$ & $\begin{array}{l}\text { The 7th HW is to be } \\
\text { assigned }\end{array}$ \\
\hline Week 14/ 11-15 May & $\begin{array}{l}\text { Text Responses (Interpretation) } \\
\text { (The Monkey's Paw by W.W. Jacobs) }\end{array}$ & $\begin{array}{l}\text { The 8th HW is to be } \\
\text { assigned }\end{array}$ \\
\hline
\end{tabular}

\section{Appendix C. Week Prompts for the First Term}

Week 1, 2, 3: Initial self-reflection: "What is your learning style? How can you apply it to reading and writing? Who are you as a writer? What are your strengths and weaknesses, likes and dislikes? What is your style? What is your process of writing?"

Week 4: "What do these recount essay assignments require from you? What do you need to know, and what skills do you need to use, to complete it? What challenges do you see?"

Week 5: "How do you feel about your progress in these assignments so far? What strategies are you using, and how? What works and what doesn't?"

Week 6: "How well do you feel you met the essay assignment requirements? What have you learned by writing it? Would you have done something differently?"

Week 7: "What do these narrative essay assignments require from you? What do you need to know, and what skills do you need to use, to complete it? What challenges do you see?"

Week 8: "How do you feel about your progress in these assignment so far? What strategies are you using, and how? What works and what doesn't?"

Week 9: "How well do you feel you met the essay assignment requirements? What have you learned by writing it? Would you have done something differently?"

Week 10: "Reflect on the exemplum essay assignment: what do you know about it? 
What does this assignment require from you? Based on your experience so far, what do you think you will need to do to write this essay successfully? What areas will be the most challenging?"

Week 11: "What type of essay are you required to write, and what do you know about this type of paper? What knowledge, skills, and strategies will you need to successfully complete it? Based on what you learned so far, what will be the most difficult areas for you, and why?"

Week 11: "Reflect on your writing experience with this essay. In what ways have you met the requirements? What were the most valuable concepts of techniques you learned? Based on this experience, how will you approach your next essay?"

Week 12: Anecdote: "Reflect on what you have done so far for this assignment. What has been your writing process? In what ways has it been successful? Based on this, how will you improve your paper?"

Week 13: "Reflect on the autobiography essay assignment: what do you know about it?

What does this assignment require from you? Based on your experience so far, what do you think you will need to do to write this essay successfully? What areas will be the most challenging?"

Week 14: "Reflect on the historical account essay assignment: what do you know about it?

What does this assignment require from you? Based on your experience so far, what do you think you will need to do to write this essay successfully? What areas will be the most challenging?"

Week 15: "Discuss what you learned about writing research that you can take with you in future courses." \& "Reflect on the first steps of the writing process. What have you learned about how to begin writing an essay and drafting? What strategies did you use? Were they effective? What could you do differently?"

Week 15: Final self-reflection (writer's self-portrait): "You are required to write a 1-page reflection on your experience in this course, a self-portrait of yourself as a writer.

Go back to your Journal and read it from the beginning. What have you discovered about yourself as a writer, a thinker, and a learner?

"The purpose of this reflection is to describe who you are as a writer, show in what ways you improved, what you accomplished. Imagine you are painting a before/after self-portrait of yourself as a writer, with your unique colours, lights and shadows. In your self-portrait, you should respond to the course learning outcome: 'Students will be able to describe personalize and apply processes appropriate for reading, writing, and learning."'

Adapted from: Hyland, K. (2007). Genre pedagogy: Language, literacy and L2 writing instruction. Journal of Second Language Writing, 16, 148-164.

\section{Appendix D. Week Prompts for the Second Term}

Week 1: Initial self-reflection: "What is your learning style? How can you apply it to reading and writing? Who are you as a writer? What are your strengths and weaknesses, likes and dislikes? What is your style? What is your process of writing?"

Week 2: "What do these explanation essay assignments require from you? What do you need to know, and what skills do you need to use, to complete it? What challenges do you see?"

Week 3: "How do you feel about your progress in these assignments so far? What strategies are you using, and how? What works and what doesn't?"

Week 4: "How well do you feel you met the essay assignment requirements? What have you learned by writing it? Would you have done something differently?"

Week 5: "What do these argument essay assignments require from you? What do you need to know, and what skills do you need to use, to complete it? What challenges do you see?"

Week 6: "How do you feel about your progress in these assignment so far? What strategies are you using, and how? What works and what doesn't?" 
Week 7: "How well do you feel you met the essay assignment requirements? What have you learned by writing it? Would you have done something differently?"

Week 8: "Reflect on the text response essay assignment: what do you know about text responses?

What does this assignment require from you? Based on your experience so far, what do you think you will need to do to write this essay successfully? What areas will be the most challenging?" (personal)

Week 9: "What type of essay are you required to write, and what do you know about this type of paper? What knowledge, skills, and strategies will you need to successfully complete it? Based on what you learned so far, what will be the most difficult areas for you, and why?" (review)

Week 10: "Reflect on your writing experience with this essay. In what ways have you met the requirements? What were the most valuable concepts of techniques you learned?

Based on this experience, how will you approach your next essay?" (interpretation)

Week 11: "Reflect on what you have done so far for this assignment. What has been your writing process? In what ways has it been successful? Based on this, how will you improve your paper?" (interpretation)

Week 12: "Discuss what you learned about writing research that you can take with you in future courses."

Week 13: "Reflect on the first steps of the writing process. What have you learned about how to begin writing an essay and drafting? What strategies did you use? Were they effective? What could you do differently?"

Week 14: Final self-reflection (writer's self-portrait): "You are required to write a 1-page reflection on your experience in this course, a self-portrait of yourself as a writer.

Go back to your Journal and read it from the beginning. What have you discovered about yourself as a writer, a thinker, and a learner?

"The purpose of this reflection is to describe who you are as a writer, show in what ways you improved, what you accomplished. Imagine you are painting a before/after self-portrait of yourself as a writer, with your unique colors, lights and shadows. In your self-portrait, you should respond to the course learning outcome: 'Students will be able to describe personalize and apply processes appropriate for reading, writing, and learning."”

Adapted from: Hyland, K. (2007). Genre pedagogy: Language, literacy and L2 writing instruction. Journal of Second Language Writing, 16, 148-164. 


\section{Appendix E. ESL Composition Profile}
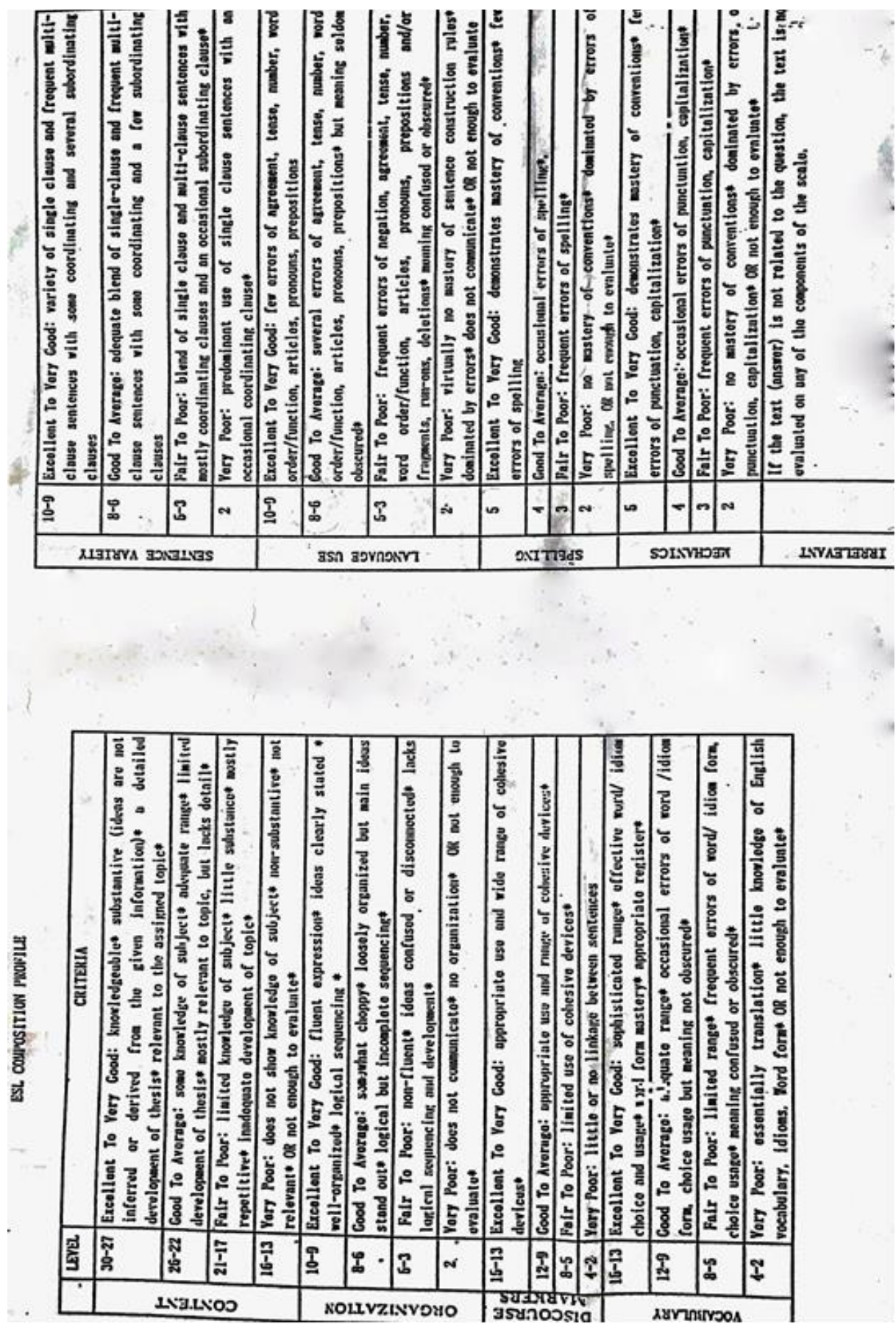

Adapted from ESL Composition Profile, Jacobs et al. 1981, p. 30 by Muşlu, M. 2007, p. 129.

\section{Copyrights}

Copyright for this article is retained by the author(s), with first publication rights granted to the Journal. This is an open-access article distributed under the terms and conditions of the Creative Commons Attribution license (CC BY-NC-ND) (http://creativecommons.org/licenses/by-nc-nd/4.0/). 